\title{
Effect of activation of wollastonite surface by quaternary ammonium salts on the relaxation properties of PVC compositions modified by it
}

\author{
C Dilyara F. Sadykova, ${ }^{1+}$ Elena M. Gotlib, ${ }^{1 *}$ \\ Ruslan V. Kozhevnikov, ${ }^{2}$ and Pablo García-Triñanes ${ }^{3}$ \\ ${ }^{1}$ Department of Synthetic Rubber Technologies, Institute of Polymers. Kazan National Research \\ Technological University. Karl Marx St., 68. Kazan, 420015. Republic of Tatarstan. Russia. \\ Phone: +7 (843) 231-42-00.E-mail: office@kstu.ru \\ ${ }^{2}$ Komiteks LIN Ltd. 2-Industrial St., 10. Syktyvkar, 167000. Republic of Komi. Russia. \\ Phone:+7 (821)228-65-01.E-mail:market@komitex.ru \\ ${ }^{3}$ Faculty of Engineering and Science, University of Greenwich. Central Avenue, Chatham Maritime, Kent. \\ ME4 4TB. United Kingdom.E-mail:p.garciatrinanes@greenwich.ac.uk
}

*Supervising author; ${ }^{+}$Corresponding author
Keywords: polyvinyl chloride, wollastonite, quaternary ammonium salts, dynamic mechanical analysis.

\begin{abstract}
It is promising to use wollastonite as a modifier of plasticized polyvinyl chloride compositions. The main advantages of wollastonite are white colour and needle-shaped particles. To improve the compatibility of this filler with a polymer matrix, it is effective to activate the surface of this mineral by quaternary ammonium salts (QAS).

Valuable information on molecular motion in modified compositions can be obtained by studying the relaxation processes using dynamic mechanical analysis.

In the temperature dependences of the mechanical loss tangent of the PVC compositions in the region of transition from the glassy to highly elastic state, two maxima were observed. It has been established that for compositions modified with both natural and surface treated wollastonite, regardless of the chemical structure of QAS used to activate the polymer.

This is probably due to the formation of a boundary layer in which molecular mobility is inhibited because of the interaction of the polymer with the filler. Thawing of segmental mobility in this boundary layer occurs at the higher temperatures than in the PVC matrix.

The surface treatment of wollastonite by QAS somewhat shifts the described relaxation transitions to higher temperatures due to an increase in the efficiency of interaction of the components at the interface.

The magnitude of the change in the temperature of the segmental mobility, both in the polymer matrix and in the boundary layer, increases with an increase in the degree of activity of the filler surface.
\end{abstract}

\section{References}

[1] Gotlib E.M., Kozhevnikov R.V. and Sadykova D.F. PVC-linoleum: classification, production methods, market analysis, recipes, properties monograph. Kazan: KNRTU. 2015. 136p. (russian)

[2] T.S. Korobshhikova. Improving the strength characteristics of polymer composite materials by modifying wollastonite. Abstract of Ph.D. Thesis. 2009. 19p. (russian)

[3] Gotlib E.M., D. Sadykova, E. Yamaleeva, R. Kozhevnikov, A. Khasanova, and E. Galimov. Wollastonite is an effective filler of rubbers and composite materials based on linear and cross-linked polymers. Moscow: LAPLambert Academic Publishing RU. 2018. 174p. (russian)

[4] E. Gotlib, D. Sadykova, Nguen Thi Lan Anh, R.V. Kozhevnikov, and A. Sokolova. Derivatives of vegetable oils as modifiers of the finishing polymer materials. Polymers in Construction. Scientific Internet-Journal. 2019. No.1. Vol 7. P.17-25. (russian)

[5] E. Gotlib, A. Khasanova, D. Sadykova, and E. Yamaleeva. Surface activation wollastinite to improve its modifying effect. Bulletin of the Technological University. 2017. Vol.20. No.22. P.37-38. (russian)

[6] Ju.V. Zelenev, G.M. Bertenev. On the mechanisms of relaxation processes in polymers of different classes. High Molecular Weight Compounds. 1972. Vol.14. No.5. P.998-1009. (russian)

[7] O.V. Starcev, A.A. Mahon'kov. Patterns of alpha transition of epoxy bonded composites according to DMA data. Bulletin of the N. Bauman Moscow State Technical University. Series "Mechanical Engineering". 2011. No.2. P.104-113. (russian) 
EFFECT OF ACTIVATION OF WOLLASTONITE SURFACE BY QUATERNARY AMMONIUM SALTS...

[8] E.M. Gotlib, D.F. Sadykova, R.V. Kozhevnikov, and E.O. Albutov. The effect of surfactants on the properties of PVC paste and linoleum on their basis. In: Proceedings of theInternational Scientific and Practical Conference"Development and solution of pressing scientific problems: questions of theory and practice". Smolensk, Russia. 2017. P.127-130. (russian)

[9] A.N. Volockoj, Ju.V. Jurkin, V.V. Avdonin. Influence of the type of filler on the dynamic properties of vibration-absorbing polymer composite materials based on ethylene vinyl acetate. Modern High Technologies. 2018. No.12. Vol.1. P.31-36. (russian)

[10] T.S. Korobshhikova, N.A. Orlova. Investigation of the granulometric composition of wollastonite of the Sinyukhinsky city and its influence on the properties of filled polymer compositions. Paints and Varnishes and their Application. 2010. No.5. P.26-29. (russian)

[11] I.D. Simonov-Emel'janov, N.V. Apeksimov, A.N. Trofimov, [and others]. Structure formation, compositions and properties of dispersed-filled polymer nanocomposites. Plastics. 2012. No.6. P.7-13. (russian)

[12] V.Ju. Masjurov. Development of PVC-compositions with controlled qualities for the production of molded moldings. Abstract of Ph.D. Thesis: Moscow. 2005. 18p. (russian)

[13] E.S. Ilicheva, E.M. Gotlib, E.N. Cherezova. Hydrophobization of wollastonite surface and study of its effect on the performance properties of rubbers based on SKI-3. Kazan Bulletin of Technological University. 2012. No.20. Vol.15. P.137-140. (russian) 